\title{
Weed Control Via InTercropping With GliRicidia. II. CoRn Crop ${ }^{1}$
}

\author{
Controle de Plantas Daninhas por Meio da Consorciação com Gliricídia. II. Cultura do Milho
}

\begin{abstract}
SILVA, P.S.L. ${ }^{2}$, CUNHA, T.M.S. ${ }^{3}$, OLIVEIRA, R.C. ${ }^{4}$, SILVA, K.M.B. ${ }^{5}$ and OLIVEIRA, O.F. ${ }^{6}$
ABSTRACT - A reduction in herbicide use is one of modern agriculture's main interests and several alternatives are being investigated with this objective, including intercropping. Gliricidia (Gliricidia sepium) mulch has no allelopathic effect on corn or beans but significantly decreased the population of some weed species. The objective of this study was to evaluate green ear and grain yield in corn cultivars as a response to weed control achieved via intercropping with gliricidia. A completely randomized block design with five replicates and split-plots was used. Cultivars AG 1051, AG 2060, BRS 2020, and PL 6880 (assigned to plots) were submitted to the following treatments: no hoeing, hoeing (performed at 20 and 40 days after sowing the corn), and corn intercropped with gliricidia. Gliricidia was grown in a transplanting system to ensure uniform germination and fast establishment in the field. Seeding was made in 200-cell trays with one seed per cell (35 mL volume). The plants emerged two to three days after sowing and were transplanted to a permanent site two to three days after emergence. Corn was sown on the same day gliricidia was transplanted. Sixteen weed species occurred at different frequencies, with uneven distribution in the experimental area. Cultivars AG 1051 and AG 2060 were the best with reference to most characteristics employed to evaluate green corn yield. Cultivar AG 1051 provided the highest grain yield. The highest green ear yield and grain yield values were obtained with hoeing. However, the fact that intercropped plots showed intermediate yield between the values obtained for hoed and non-hoed plots indicates that gliricidia was beneficial to corn, and exerted a certain level of weed control.
\end{abstract}

Keywords: Zea mays, Gliricidia sepium, cultivars, green corn, grain yield.

\begin{abstract}
RESUMO - Um dos principais interesses da agricultura moderna é a redução no uso de herbicidas; para isso, diversas alternativas estão sendo investigadas, inclusive a consorciação. A cobertura do solo com ramos de gliricídia (Gliricidia sepium) não tem efeito alelopático sobre o milho ou feijão, mas diminui significativamente a população de algumas espécies de plantas daninhas. $O$ objetivo deste estudo foi avaliar os rendimentos de espigas verdes e de grãos de cultivares de milho, em resposta ao controle de plantas daninhas, por meio da consorciação com gliricídia. Utilizou-se o delineamento de blocos ao acaso com parcelas subdivididas e cinco repetições. Os cultivares 1051, AG 2060, BRS 2020 e PL 6880 (atribuidos às parcelas) foram submetidos aos seguintes tratamentos: sem capina, duas capinas (realizadas aos 20 e 40 dias após a semeadura) e consorciação com gliricídia. Esta planta foi cultivada em um sistema de transplantio, para garantir germinação uniforme e rápido estabelecimento no campo. A semeadura foi feita em bandejas de 200 células, com uma semente por célula (volume de $35 \mathrm{~mL}$ ). As plantas emergiram dois a três dias após a semeadura e foram transplantadas para o local definitivo dois a três dias após a emergência. O milho foi semeado no mesmo dia em que a gliricídia foi transplantada. Dezesseis espécies de plantas daninhas ocorreram em diferentes frequências, com distribuição desuniforme na área experimental. Os cultivares AG 1051 e AG 2060 foram os melhores quanto à maioria das características avaliadoras do rendimento de milho verde. O cultivar AG 1051 foi o melhor quanto ao rendimento de grãos. Os maiores rendimentos de espigas verdes e de grãos foram obtidos com
\end{abstract}

Recebido para publicação em 20.5.2008 e na forma revisada em 18.2.2009.

2 Universidade Federal Rural do Semi-Árido - UFERSA, Caixa Postal 137, 59625-900 Mossoró-RN. CNPq fellow. <paulosergio@ufersa.edu.br>; ${ }^{3}$ UFERSA, Mossoró-RN, CNPq fellow, <paulosergio@ufersa.edu.br>; ${ }^{4}$ UFERSA, Mossoró-RN, $<$ reginacelia@ufersa.edu.br>; ${ }^{5}$ Universidade do Estado do Rio Grande do Norte - UERN, Caixa Postal 70, 59610-090 Mossoró-RN, < kmbsbarbosa@yahoo.com.br>; ${ }^{6}$ UFERSA, Mossoró-RN, <odaci@uol.com.br>. 
duas capinas. Todavia, o fato de as parcelas consorciadas terem apresentado médias intermediárias às médias das parcelas não-capinadas e capinadas-em algumas características avaliadoras do rendimento de espigas verdes e no rendimento de grãos - indica que a gliricídia foi benéfica ao milho e exerceu certo controle sobre as plantas daninhas.

Palavras-chave: Zea mays, Gliricidia sepium, cultivares, milho-verde, rendimento de grãos.

\section{INTRODUCTION}

The adoption of the intercropping system is usually justified by its better use of environmental resources, compared to monocropping (Fukai \& Trenbath, 1993). In addition, intercropping is also indicated as an alternative to herbicide use, by reducing or suppressing weed growth (Liebman \& Davis, 2000). Reduction in herbicide use is one of modern agriculture's main interests (Ngouajio et al., 1999) and several alternatives are being investigated with this objective, including intercropping (Carruthers et al., 1998). The effects of cover crop are achieved by a rapid occupation of the open space between the rows of the main crop, which prevents germination of weed seeds and reduces weed growth and development. Germination of weed seeds may be inhibited by complete light interception by the cover crop or by secretion of allelochemicals. After the establishment of the weed seedlings, resource competition becomes the cover crop's main weed suppressing mechanism (Hollander et al., 2007). The decrease in weed incidence in corn through intercropping is dependent on several factors, such as corn cultivar, climate conditions (Kuchinda et al., 2003), sowing time, intercropped species (Skóra Neto, 1993) and fertilizer rates (Olasantan et al., 1994).

Shifting cultivation systems are very common in the semi-arid region of Brazil. Areas are deforested and the plant waste resulting from deforestation is burned to clear the area intended to be occupied by crops. Such burning causes soil impoverishment and, after only a few years of cultivations, the exploited areas are abandoned and new areas are deforested. Agroforestry systems similar to those employed in other semi-arid regions are also being used in the Brazilian Northeastern region. As an alternative to the existing shifting cultivation systems in the tropics, farmers are being encouraged to adopt agroforestry systems in which trees contribute to pruning, which may be used to mulch the associated crops. Gliricidia sepium, Leucaena leucocephala and Senna siamea are widely tested trees for agroforestry technologies (Kamara et al., 2000). However, in addition to soil improvement, mulching material also suppresses weed growth (Budelman, 1988). Weed growth has been shown to be suppressed in alley cropping by canopy closure (Yamoah et al., 1986). In addition to physical suppression of weeds, the decomposition of plant residues can also release phytotoxic compounds that inhibit crop and weed growth (Tian \& Kang, 1994). Plant species differ in their response to phytotoxic plant residues. G. sepium mulch had no allelopathic effect on corn or beans but significantly decreased the population of some weed species (Obando, 1987). Mulches from $G$. sepium and $S$. siamea reduced weed density and weed biomass, while L. leucocephala was less effective in reducing weed biomass and weed density (Kamara et al., 2000). These results led to the idea of evaluating the effects of gliricidia on weed control in corn. Gliricidia is an arboreal legume from Mexico that belongs to the Fabaceae family. It is a fast-growing tree that may reach 15 meters in height, with deep rooting, which gives it good tolerance to drought. It can be propagated both sexually and asexually (Drumond \& Carvalho Filho, 2005). It easily withstands periodical prunings, due to its high regrowth capacity. It is considered a multi-use species, since it is employed in green fertilization, reforestation, and as forage or hedge, among other uses (Carvalho Filho et al., 1997).

No data were found in the consulted literature comparing soil cover and intercropping (live mulch) on weed control in corn. In rice, though the dry weight of grass weeds at 30 days after seeding was lower with intercropping with Sesbania rostrata than with 
wheat residue mulch, they were similar at latter stages. A lower broadleaved weed density and dry weight were observed with Sesbania than with mulch. It was concluded that application of wheat $4 \mathrm{tha}^{-1}$ of residue mulch and Sesbania intercropping for 30 days were equally effective in controlling weeds associated with dry-seeded rice (Singh et al., 2007).

The objective of this study was to evaluate green ear and grain yield in corn cultivars as a response to weed control achieved via intercropping with gliricidia. The effects of gliricidia intercropped with cotton on naturallycolored cotton fiber yield are presented in a different paper (Anonymous).

\section{MATERIAL AND METHODS}

The experiment was carried out at the "Rafael Fernandes" Experimental Farm at the Universidade Federal Rural do Semi-Árido (UFERSA), $20 \mathrm{~km}$ in Mossoró-RN, Brazil (5 ${ }^{\circ}$, latitude, $37^{\circ} 20^{\prime} \mathrm{WGr}$ longitude and an altitude of $18 \mathrm{~m}$ ). The experiment was sprinklerirrigated with a $5.6 \mathrm{~mm}$ water depth and a oneday watering schedule. The water depth required was calculated considering an effective depth of the root system of $0.40 \mathrm{~m}$. Irrigation time was based on the water retained by the soil at a tension of $0.04 \mathrm{Mpa}$. According to Gaussen's bioclimatic classification, the climate in the Mossoro region is of the 4ath type, i.e., distinctly xerothermic, which means hot tropical and with accentuated drought, with a long 7 to 8 month season and a xerothermic index between 150 and 200. According to Köppen, the region's bioclimate is BSwh, i.e., hot, with greater precipitation delaying into autumn. The region has an average minimum air temperature ranging between 21.3 and $23.7^{\circ} \mathrm{C}$ and an average maximum temperature between 32.1 and $34.5^{\circ} \mathrm{C}$, with June and July as the coolest months, and average annual precipitation of around $825 \mathrm{~mm}$

A completely randomized block design with five replicates and split-plots was used. Cultivars AG 1051, AG 2060, BRS 2020, and PL 6880 (assigned to plots) were submitted to the following treatments: no hoeing, hoeing (performed at 20 and 40 days after sowing the corn), and corn intercropped with gliricidia.
Each subplot consisted of four 6.0m-length rows, but only the two central rows were considered as an experimental plot, discarding the border rows and the two plants at each row extremity. The gliricidia was grown in a transplantation system to ensure uniform germination and fast establishment in the field. Seeding was made in 200-cell trays with one seed per cell (35 mL volume), on 06.21.06. The substrate for the cells was prepared with $1 / 3$ vermicompost and 2/3 soil classified as a Red-Yellow Argisol (PVA), according to the Brazilian Soils Classification System (Embrapa, 1999) and as Ferric Lixisol according to the Soil Map of the World (FAO, 1988). The analysis (Embrapa, 1999) of a vermicompost sample indicated: $\mathrm{pH}=7.90 ; \mathrm{P}=120.1 \mathrm{mg} \mathrm{kg}^{-1}$; $\mathrm{K}^{+}=0.67 \mathrm{cmol}_{\mathrm{c}} \mathrm{dm}^{-3} ; \mathrm{Ca}^{2+}=19.50 \mathrm{cmol} \mathrm{dm}^{-3}$; $\mathrm{Mg}^{2+}=15.00 \mathrm{cmol}_{\mathrm{c}} \mathrm{dm}^{-3} ; \mathrm{Al}^{3+}=0.00 \mathrm{cmol}_{\mathrm{c}} \mathrm{dm}^{-3}$; $\mathrm{Na}^{+}=0.19 \mathrm{cmol}_{\mathrm{c}} \mathrm{dm}^{-3}$. Analysis (Embrapa, 1999) of the soil substrate indicated: $\mathrm{pH}=7.20$; $\mathrm{P}=51.97 \mathrm{mg} \mathrm{kg}^{-1} ; \mathrm{K}^{+}=0.20 \mathrm{cmol}_{\mathrm{c}} \mathrm{dm}^{-3} ; \mathrm{Ca}^{2+}=$ $4.50 \mathrm{cmol}_{\mathrm{c}} \mathrm{dm}^{-3} ; \mathrm{Mg}^{2+}=1.60 \mathrm{cmol}_{\mathrm{c}} \mathrm{dm}^{-3} ; \mathrm{Al}^{3+}=$ $0.00 \mathrm{cmol}_{\mathrm{c}} \mathrm{dm}^{-3} ; \mathrm{Na}^{+}=0.10 \mathrm{cmol}_{\mathrm{c}} \mathrm{dm}^{-3}$. The plants emerged two to three days after sowing and were transplanted to the permanent site two to three days after emergence. Corn was sown on the day gliricidia was transplanted. The soil at the permanent site was tilled by means of two harrowings. This soil, also classified as a Red-Yellow Argisol (PVA), was analyzed based on samples collected at a 0-20 cm depth; the analysis (Embrapa, 1999) indicated: $\mathrm{pH}=6.70 ; \mathrm{P}=60.70 \mathrm{mg} \mathrm{kg}^{-1} ; \mathrm{K}^{+}=$ $0.21 \mathrm{cmol}_{\mathrm{c}} \mathrm{dm}^{-3} ; \mathrm{Ca}^{2+}=4.20 \mathrm{cmol}_{\mathrm{c}} \mathrm{dm}^{-3} ; \mathrm{Mg}^{2+}=$ $1.60 \mathrm{cmol}_{\mathrm{c}} \mathrm{dm}^{-3} ; \mathrm{Al}^{3+}=0.00 \mathrm{cmol}_{\mathrm{c}} \mathrm{dm}^{-3} ; \mathrm{Na}^{+}=$ $0.18 \mathrm{cmol}_{\mathrm{c}} \mathrm{dm}^{-3}$. The corn was fertilized with $30 \mathrm{~kg} \mathrm{ha}^{-1}$ of $\mathrm{N}$ (1/3 of total $\mathrm{N}$ applied), $60 \mathrm{~kg} \mathrm{ha}^{-1}$ of $\mathrm{P}_{2} \mathrm{O}_{5}$, and $30 \mathrm{~kg} \mathrm{ha}^{-1}$ of $\mathrm{K}_{2} \mathrm{O}$ per ha. The remaining $\mathrm{N}$ was applied in equal parts after each hoeing. Ammonium sulfate, single superphosphate, and potassium chloride were used as sources of $\mathrm{N}, \mathrm{P}_{2} \mathrm{O}_{5}$, and $\mathrm{K}_{2} \mathrm{O}$, respectively. The corn was seeded at a $1.0 \mathrm{~m} \times 0.4 \mathrm{~m}$ spacing, with four seeds per pit. A thinning operation was performed 20 days after sowing, leaving the two more vigorous plants in each pit. Gliricidia was seeded between the corn rows in pits spaced $0.5 \mathrm{~m}$ apart, containing one plant/pit. Control of fall armyworm (Spodoptera frugiperda Smith), the main corn pest in the region, was made with two deltamethrin sprays $\left(250 \mathrm{~mL} \mathrm{ha}^{1}\right)$, at 7 and 14 days after sowing. 
One of the two usable rows was selected to evaluate green ear yield, while the other was used to assess grain yield and its components. Green corn was harvested at 73 and 75 days after sowing, and green ear yield was evaluated by the total number and weight of ears and number and weight of marketable ears, either unhusked or husked. Ears with a length equal to or above $22 \mathrm{~cm}$ and without signs of attack by pests were considered as marketable unhusked ears. The marketable husked ears were considered as those with a length equal to or above $18 \mathrm{~cm}$ that showed health and grain set suitable for commercialization. Plant height and ear height (in all usable plants in the plot), as well as leaf area and biomass of the root system were evaluated after the last green corn harvest. The distance from ground level to the insertion point of the highest leaf blade was considered as plant height. The distance from the ground level to the insertion point of the highest ear was considered as ear height. Leaf area was estimated with a LI 3100 (LI-COR Inc.) electronic measuring device, based on the area of all leaves from the four plants used to estimate root system biomass. The root system was removed from the soil with a hoe, and pits measuring $0.2 \mathrm{~m}$ (length) $\times$ $0.2 \mathrm{~m}$ (width) $\times 0.2 \mathrm{~m}$ were dug around each pit of a set of two planting pits. Dry root biomass was obtained by placing a ground and homogenized root system sample (500 g) from those four plants into a forced air circulation oven, adjusted to $75^{\circ} \mathrm{C}$.

Grain yield was estimated from mature corn ears, harvested in the other usable row. The number of ears ha ${ }^{-1}$ was estimated based on the number of these ears. The number of kernels per ear was estimated based on a 10-ear sample. One-hundred-kernel weight was estimated based on the weight and number of kernels in those ears. Grain yield was corrected for a moisture content of $15.5 \%$ (wet basis).

Gliricidia and weed characteristics were evaluated after the dry corn was harvested, 100 days after sowing. Plant height (from ground level to the plant's top) and biomass of the above ground part were evaluated in gliricidia with samples consisting of three plants. Biomass of the above-ground part of the weeds was evaluated by cutting the weed species even with the ground in a $1.0 \mathrm{~m} \times$ $0.8 \mathrm{~m}$ area, at the central part of each subplot. The species were classified botanically and weed distribution in the experiment area was determined in conformity with the randomization of the experimental units. Based on the information on the occurrence of weeds in each subplot, the index of occurrence was calculated, as defined by the ratio between the number of plots where each species occurred and the total number of experimental plots (60). Estimation of the gliricidia and weed biomass values was similar to that of corn root biomass.

The data were submitted to analysis of variance using the software developed at the Federal University of Viçosa (UFV), MG, Brazil (SAEG, 2007) and the means were compared by the Tukey test $(\mathrm{P}<0.05)$.

\section{RESULTS AND DISCUSSION}

Sixteen weed species occurred in the experiment (Table 1), most of them belonging to the family Poaceae. Such small number of species could be associated with the intensive cultivation of corn in the area where the experiment was conducted (two cultivations per year, over almost ten years). Usually, weed biomass as well as weed density and diversity, are smaller in traditional cultivations (intensive soil tillage and high doses of chemical products), intermediate in reduced tillage systems, and higher in organic systems (Menalled et al., 2001). The weed population in a given area depends on several factors, and although the population comprises different species, few of them are predominant, corresponding to 70 to $90 \%$ of the species total (Buhler, 1999). Some species occurred more frequently than others. The species Commelina benghalenis, for example, occurred in $93 \%$ of the experimental units, while the species Blainvillea latifolia, Desmanthus virgatus, Melochia pyramidata, Phyllanthus amarus and Senna accidentalis occurred at frequencies around $2 \%$ (Table 1).

There was no effect of the cultivars $\times$ weed control interaction on the characteristics evaluated. For this reason, only the means for the main effects of both treatment groups are presented here (Tables 2 to 5). 
Table 1 - Index of occurrence (ratio between the number of experimental units in which a species occurred and the total number of experimental units) for the main weed species identified in the experiment area

\begin{tabular}{|c|l|l|c|}
\hline $\begin{array}{c}\text { Order } \\
\mathrm{n} \text { - }\end{array}$ & \multicolumn{1}{|c|}{ Botanical name } & \multicolumn{1}{|c|}{ Family } & Index of occurrence \\
\hline 1 & Acanthospermum hispidum L. & Compositae & 0.03 \\
\hline 2 & Alternanthera tenella Colla & Amaranthaceae & 0.66 \\
\hline 3 & Amaranthus viridis L. & Amaranthaceae & 0.23 \\
\hline 4 & Blainvillea latifolia (L.f.) D.C. & Compositae & 0.02 \\
\hline 5 & Cenchrus echinatus L. & Poaceae & 0.12 \\
\hline 6 & Commelina benghalenis L. & Commelinaceae & 0.93 \\
\hline 7 & Cucumis anguria L. & Cucurbitaceae & 0.73 \\
\hline 8 & Desmanthus virgatus (L.) Willd. & Leg. Mimosoideae & 0.02 \\
\hline 9 & Ipomoea bahiensis Willd. Ex Roem et \& Schult & Convolvulaceae & 0.06 \\
\hline 10 & Melochia pyramidata L. & Sterculiaceae & 0.02 \\
\hline 11 & Merremia aegyptia (L.) Urban & Convolvulaceae & 0.12 \\
\hline 12 & Panicum maximum Jacq. & Poaceae & 0.03 \\
\hline 13 & Phyllanthus amarus Schumach. et Thonn & Euphorbiaceae & 0.02 \\
\hline 14 & Physalis angulata L. & Solanaceae & 0.03 \\
\hline 15 & Senna accidentalis (L.) Link & Leg. Caesalpinioideae & \\
\hline 16 & Spigelia anthelmia L. & Loganiaceae & 0.02 \\
\hline
\end{tabular}

The cultivars did not have an influence on dry matter of the above-ground part $\left(5.5 \mathrm{~g} \mathrm{~m}^{-2}\right.$ on average) and plant height in gliricidia (48.2 $\mathrm{cm}$ on average), or dry matter of the aboveground part (227.7 $\mathrm{g} \mathrm{m}^{-2}$ on average) and leaf area $\left(5249 \mathrm{~cm}^{2}\right.$ per plant on average). Dry matter of the above-ground part of the weeds in the hoed plots $\left(98.1 \mathrm{~g} \mathrm{~m}^{-2}\right)$ was smaller than in the plots where corn was intercropped with gliricidia $\left(287.1 \mathrm{~g} \mathrm{~m}^{-2}\right)$ or in the non-hoed plots $\left(298.0 \mathrm{~g} \mathrm{~m}^{-2}\right)$, which were not different from each other. Weed control did not influence plant height ( $204 \mathrm{~cm}$ on average), ear height (115 cm on average), and dry matter of the root system in corn ( $35.4 \mathrm{~g}^{-1}$ root system, on average).

Cultivar PL 6880 had the highest plant height and ear height values, while cultivar AG 2060 had the highest dry matter weight of the root system (Table 2). The cultivars were not different with regard to total number of green ears and number of marketable unhusked ears, but cultivars AG 1051 and AG 2060 were the best with reference to the other characteristics used to evaluate green corn (Table 2).

The leaf area of corn intercropped with gliricidia was intermediate between the leaf areas obtained in hoed and non-hoed plots (Table 3). Weed control did not influence the total number of green ears, but hoed plots were superior in the other characteristics used to evaluate green ear yield (Table 6). It is interesting to point out that the average values for total weight of unhusked ears and number of marketable unhusked ears in the treatment where corn was intercropped with gliricidia were intermediate between the corresponding means obtained in hoed and non-hoed plots (Table 3).

There were no differences between cultivars with regard to the number of mature ears, similarly to what was observed for total number of green ears (Table 4). However, cultivar AG 1051 was the best in terms of number of kernels per ear (cultivar AG 2060 was also superior for this trait), 100-kernel weight, and grain yield (Table 4).

Weed control did not have an influence on the number of mature ears and 100-kernel weight, but the highest values of kernels per ear and grain yield were obtained in hoed plots (Table 5). Corn grain yield in plots intercropped with gliricidia was intermediate between the values obtained in hoed and non-hoed plots (Table 5). 
Table 2 - Plant height, ear height, root biomass, and green ear yield of corn cultivars under different weed control methods (means over method of weed control $)^{1^{\prime}}$

\begin{tabular}{|c|c|c|c|c|c|c|c|c|c|}
\hline \multirow{2}{*}{$\begin{array}{l}\text { Corn } \\
\text { cultivar }\end{array}$} & \multirow{2}{*}{$\begin{array}{l}\text { Plant } \\
\text { height } \\
(\mathrm{cm})\end{array}$} & \multirow{2}{*}{$\begin{array}{l}\text { Ear } \\
\text { height } \\
(\mathrm{cm})\end{array}$} & \multirow{2}{*}{$\begin{array}{c}\text { Root } \\
\text { biomass } \\
\left(\mathrm{g} \mathrm{root} \mathrm{system}^{-1}\right)\end{array}$} & \multicolumn{2}{|c|}{ Total green ears with husks } & \multicolumn{2}{|c|}{$\begin{array}{c}\text { Marketable green ears with } \\
\text { husks }\end{array}$} & \multicolumn{2}{|c|}{$\begin{array}{c}\text { Marketable green ears } \\
\text { without husks }\end{array}$} \\
\hline & & & & Number ha $^{-1}$ & $\begin{array}{c}\text { Yield } \\
\left(\mathrm{kg} \mathrm{ha}^{-1}\right)\end{array}$ & Number ha $^{-1}$ & $\begin{array}{c}\text { Yield } \\
\left(\mathrm{kg} \mathrm{ha}^{-1}\right)\end{array}$ & Number ha $^{-1}$ & $\begin{array}{c}\text { Yield } \\
\left(\mathrm{kg} \mathrm{ha}^{-1}\right)\end{array}$ \\
\hline AG 1051 & $199 \mathrm{~b}$ & $114 \mathrm{~b}$ & $26.9 \mathrm{~b}$ & $49030 \mathrm{a}$ & $15673 \mathrm{a}$ & $45809 \mathrm{a}$ & $15258 \mathrm{a}$ & $38908 \mathrm{a}$ & $8566 \mathrm{a}$ \\
\hline AG 2060 & $205 \mathrm{ab}$ & $107 \mathrm{~b}$ & $50.5 \mathrm{a}$ & $50624 \mathrm{a}$ & 16079 a & $49013 \mathrm{a}$ & 15746 a & $39423 \mathrm{a}$ & $8604 \mathrm{a}$ \\
\hline BRS 2020 & $197 \mathrm{~b}$ & $109 \mathrm{~b}$ & $33.5 \mathrm{ab}$ & 49639 a & $13606 \mathrm{~b}$ & 45887 a & $13140 \mathrm{~b}$ & $31999 \mathrm{~b}$ & $5886 \mathrm{c}$ \\
\hline PL 6880 & $216 \mathrm{a}$ & $131 \mathrm{a}$ & $30.8 \mathrm{ab}$ & 49893 a & $14951 \mathrm{ab}$ & 46369 a & $14440 \mathrm{ab}$ & $37057 \mathrm{ab}$ & $7211 b$ \\
\hline $\mathrm{CVa}, \%$ & 5.4 & 8.2 & 44.0 & 4.6 & 10.5 & 9.1 & 12.0 & 12.9 & 15.6 \\
\hline
\end{tabular}

${ }^{1 /}$ Means followed by the same letters in the column do not differ by the Tukey's test $(\mathrm{P}<0.05)$.

Table 3 - Leaf area and green ear yield of corn cultivars under different weed control methods (means over corn cultivars) $)^{1 /}$

\begin{tabular}{|c|c|c|c|c|c|c|c|}
\hline \multirow{2}{*}{$\begin{array}{l}\text { Weed control } \\
\text { methods }\end{array}$} & \multirow{2}{*}{$\begin{array}{c}\text { Leaf area } \\
\left(\mathrm{cm}^{2} \text { per plant }\right)\end{array}$} & \multicolumn{2}{|c|}{ Total green ears with husks } & \multicolumn{2}{|c|}{ Marketable green ears with husks } & \multicolumn{2}{|c|}{$\begin{array}{l}\text { Marketable green ears } \\
\text { without husks }\end{array}$} \\
\hline & & Number ha $^{-1}$ & Yield $\left(\mathrm{kg} \mathrm{ha}^{-1}\right)$ & Number ha ${ }^{-1}$ & Yield $\left(\mathrm{kg} \mathrm{ha}^{-1}\right)$ & Number ha ${ }^{-1}$ & Yield $\left(\mathrm{kg} \mathrm{ha}^{-1}\right)$ \\
\hline Hoeing & $5719 a$ & $50247 \mathrm{a}$ & $16065 \mathrm{a}$ & $47882 \mathrm{a}$ & $15757 \mathrm{a}$ & $40175 \mathrm{a}$ & $8485 \mathrm{a}$ \\
\hline With G. sepium & $5091 \mathrm{ab}$ & $50623 \mathrm{a}$ & $15124 \mathrm{ab}$ & $46750 \mathrm{ab}$ & $14585 \mathrm{~b}$ & $36485 \mathrm{~b}$ & $7471 \mathrm{~b}$ \\
\hline No-hoeing & $4937 \mathrm{~b}$ & $48519 \mathrm{a}$ & $14042 \mathrm{~b}$ & $45676 \mathrm{~b}$ & $13597 \mathrm{~b}$ & $33881 \mathrm{~b}$ & $6745 \mathrm{~b}$ \\
\hline $\mathrm{CVb}, \%$ & 15.6 & 6.9 & 9.9 & 5.9 & 10.0 & 10.7 & 12.6 \\
\hline
\end{tabular}

${ }^{1 /}$ Means followed by the same letters in the column do not differ by the Tukey's test $(\mathrm{P}<0.05)$.

Table 4 - Grain yield and its components of corn cultivars under different weed control methods (means over weed control methods $)^{1 /}$

\begin{tabular}{|l|c|c|c|c|}
\hline Corn cultivar & $\begin{array}{c}\text { Number of } \\
\text { mature } \\
\text { ears ha }^{-1}\end{array}$ & $\begin{array}{c}\text { Number of } \\
\text { grain per } \\
\text { ears }\end{array}$ & $\begin{array}{c}100 \text {-seed } \\
\text { weight }(\mathrm{g})\end{array}$ & $\begin{array}{c}\text { Grain yield } \\
\left(\mathrm{kg} \mathrm{ha}^{-1}\right)\end{array}$ \\
\hline AG 1051 & $50,321 \mathrm{a}$ & $483.4 \mathrm{a}$ & $34.4 \mathrm{a}$ & $8,274 \mathrm{a}$ \\
\hline AG 2060 & $50,000 \mathrm{a}$ & $517.3 \mathrm{a}$ & $28.6 \mathrm{~b}$ & $7,683 \mathrm{ab}$ \\
\hline BRS 2020 & $51,204 \mathrm{a}$ & $415.6 \mathrm{~b}$ & $32.2 \mathrm{ab}$ & $6,621 \mathrm{~b}$ \\
\hline PL 6880 & $50,725 \mathrm{a}$ & $492.4 \mathrm{a}$ & $30.5 \mathrm{~b}$ & $7,737 \mathrm{ab}$ \\
\hline CVa, plots (\%) & 2.5 & 5.6 & 9.0 & 13.9 \\
\hline
\end{tabular}

1/ Means followed by the same letters in the column do not differ by the Tukey's test $(\mathrm{P}<0.05)$

Not always the best cultivars for green ear yield (Table 2) were also the best for grain yield (Table 5). It is expected that ears unsuitable to be marketed as green corn (very small, with poor grain set, attacked by pests, etc.) can be perfectly used for mature grain.

As previously mentioned, gliricidia determined smaller dry matter weight of the above-ground part of weeds than non-hoeing, although the difference was not significant.
However, the fact that intercropped plots showed intermediate means between the values obtained for hoed and non-hoed plots for leaf area (Table 3), green ear yield (Table 3), and grain yield (Table 5) indicates that gliricidia was beneficial to corn. Such benefit was probably due to a certain degree of weed control. Such effect of gliricidia on weeds would probably be due to allelopathy, in addition to competition with weeds for water, light, and nutrients (Obando, 1987; Kamara et al., 2000).

Table 5 - Grain yield and its components of corn cultivars under different weed control methods (means over weed control methods $)^{1}$

\begin{tabular}{|l|c|c|c|c|}
\hline $\begin{array}{c}\text { Weed control } \\
\text { methods }\end{array}$ & $\begin{array}{c}\text { Number of } \\
\text { mature } \\
\text { ears ha }\end{array}$ & $\begin{array}{c}\text { Number of } \\
\text { grain per } \\
\text { ears }\end{array}$ & $\begin{array}{c}100 \text {-seed } \\
\text { weight }(\mathrm{g})\end{array}$ & $\begin{array}{c}\text { Grain } \\
\text { yield } \\
\left(\mathrm{kg} \mathrm{ha}^{-1}\right)\end{array}$ \\
\hline Hoeing & $51,024 \mathrm{a}$ & $504.8 \mathrm{a}$ & $31.2 \mathrm{a}$ & $8,019 \mathrm{a}$ \\
\hline With G. sepium & $50,392 \mathrm{a}$ & $470.2 \mathrm{~b}$ & $30.9 \mathrm{a}$ & $7,467 \mathrm{ab}$ \\
\hline No-hoeing & $50,272 \mathrm{a}$ & $456.6 \mathrm{~b}$ & $32.2 \mathrm{a}$ & $7,251 \mathrm{~b}$ \\
\hline $\mathrm{CVb}$, subplots $(\%)$ & 2.4 & 7.0 & 7.7 & 11.0 \\
\hline
\end{tabular}

${ }^{1}$ Means followed by the same letters in the column do not differ by Tukey's test $(\mathrm{P}<0.05)$ 
The weeds reduced most of the evaluated characteristics in this study (Tables 3 and 5). Weeds reduce crop yield by competing with them for water, nutrients and light (Carruthers et al., 1998). But another aspect must be involved. Corn root system is less developed with weed presence (Thomas \& Allison, 1975). Thus, a smaller corn root system due to weed presence would be less efficient in nutrient absorption. Water content in corn plots with weeds was greater than in the crop plots without weeds (Thomas \& Allison, 1975). Development of water stress symptoms with the presence of weeds may not be caused by water availability, but by the reduced ability to absorb water through the root system. Therefore, despite the fact that the experiment on which this study was based used irrigation, the reduction in the corn root system caused by the weeds would reduce water absorption capacity. Water deficiency induces the closing of stomata thus paralyzing photosynthesis and drastically reducing production in corn competing with weeds (Silva et al., 2004). This problem is aggravated if there are $\mathrm{C}_{4}$ weeds in the area, such as the Cenchrus echinatus (Table 1) that, like corn, are highly efficient in water use (Silva et al., 2004). Another possibility would be the invader root exudates that could inhibit corn root growth (Rajcan \& Swanton, 2001).

Two components are involved in the competition for light: the quantity and quality of light. The quantitative component of light determines photosynthetic activity, whereas the quality of light influences plant morphology. An important characteristic of corn is that most of the light is intercepted by the younger, more efficient leaves above the ear and less than $10 \%$ of the photon flux density (PFD) reaches the leaves below $1 \mathrm{~m}$. Thus, direct competition for PFD between corn and weeds is relatively small. Leaf area index (LAI) defines the ability of a plant to intercept PFD and it is an important factor determining for the accumulation of dry matter. A high degree of competition with weeds was seen (Tollenaar et al., 1994) to reduce corn LAI at blooming by $15 \%$. Thus, grain yield loss resulting from competition for light is best explained through the reduction in LAI than in lower photosynthetic rates of shaded leaves (Rajcan
\& Swanton, 2001). Actually, in this study a reduction was observed in the corn leaf area (Table 3), which agrees with other authors, (Aflakpui et al., 2002), due to weed competition.

The lower leaves are not only exposed to a reduced amount of $\mathrm{PFD}$, but they also receive a quality of light that differs from the total sunlight received by the upper leaves. The light within the crown is rich in far red radiation, FR $(730$ at $740 \mathrm{~nm})$. This is caused by the selective absorption of red light, $R(660-670 \mathrm{~nm})$ by photosynthetic pigments and the reflection of FR light by green leaves. This makes the far-red/red (FR/R) ratio greater in the lower part of the crown than on the upper part of the crown. Although weeds generally do not shade corn, there are indications that corn grown in the presence of weeds receives a greater $\mathrm{FR} / \mathrm{R}$ ratio than the weed free crop (Rajcan $\&$ Swanton, 2001).

Therefore, it can be concluded that sixteen weed species occurred at different frequencies, with uneven distribution in the experiment area. Cultivars AG 1051 and AG 2060 were the best with reference to most characteristics employed to evaluate green corn yield. Cultivar 1051 was the best with regard to grain yield. The highest green ear yield and grain yield values were obtained with hoeing. However, the fact that intercropped plots showed intermediate means between the values obtained for hoed and non-hoed plots with regard to leaf area and some trait used to evaluate green ear yield and grain yield, indicates that gliricidia was beneficial to corn, and exerted a certain level of weed control.

\section{LITERATURE CITED}

AFLAKPUI, G. K. S.; GREGORY, P. J.; FROUDWILLIAMS, R. J. Growth and biomass partitioning of maize during vegetative growth in response to Striga hermonthica infection and nitrogen supply. Exper. Agric., v. 38, n. 1, p. $265-276,2002$.

BUDELMAN, A. The performance of leaf mulches of Leucaena leucocephala, Flemigia macrophylla, and Gliricidia sepium in weed control. Agrofor. Syst., v. 6, n. 1, p. 137-145, 1988.

BUHLER, D. D. Weed population responses to weed control practices. I. Seed bank, weed populations, and crop yields. Weed Sci., v. 47, n. 4, p. 416-422, 1999. 
CARRUTHERS, $\mathrm{K}$. et al. Intercropping corn with soybean, lupin and forages: weed control by intercrops combined with interrow cultivation. Eur J. Agron., v. 8, n. 3/4, p. 225-238, 1998.

CARVALHO FILHO, O. M.; DRUMOND, M. A.; LANGUIDEY, P. H. Gliricidia sepium - leguminosa promissora para regiões semi-áridas. Petrolina: EmbrapaCPATSA, 1997. 16 p. (Circular Técnica, 35).

DRUMOND, M. A.; CARVALHO FILHO, O. M. Espécies vegetais exóticas com potencialidades para o semi-árido brasileiro. Brasília: Embrapa semi-árido/Embrapa Informação Tecnológica, 2005. 340 p

EMPRESA BRASILERA DE PESQUISAAGROPECUÁRIA - EMBRAPA. Centro Nacional de Pesquisa do Solo. Sistema brasileiro de classificação de solos. Brasília: Serviço de Produção de Informação, 1999. 412 p.

FAO. Soil map of the world; revised legend. Rome UNESCO, 1988. $119 \mathrm{p}$

FUKAI, S.; TRENBATH, B. R. Processes determining intercrop productivity and yields of components crops. Field Crops Res., v. 34, n. 3/4, p. 247-271, 1993.

HOLLANDER, N. G.; BASTIAANS, L.; KROPFF, M. J. Clover as a cover crop for weed suppression in a intercropping design. I. Characteristics of several clover species. Eur. J. Agron., v. 26, n. 2, p. 92-103, 2007.

KAMARA, A. Y. et al. Selective control of weeds in an arable crop by mulches from some multipurpose trees in

Southwestern Nigeria. Agrofor. Syst., v. 50, n. 1, p. 17-26, 2000 .

KUCHINDA N. C. et al. On-farm evaluation of improved maize varieties intercropped with some legumes in the control of Striga in the Northern Guinea savanna of Nigeria. Crop Prot., v. 22, n. 3, p. 533-538, 2003.

LIEBMAN, M.; DAVIS, A. S. Integration of soil, crop and weed management in low-input farming systems. Weed Res., v. 40, n. 1, p. $27-47,2000$.

MENALLED, F. D.; GROSS, K. L.; HAMMOND, M. Weed aboveground and seedbank community responses to agricultural management systems. Ecol. Appl., v. 11, n. 6, p. $1586-1601,2001$

NGOUAJO, M.; LEMIEUX, C.; LEROUX, G. D Prediction of corn (Zea mays) yield loss from early observations of the relative leaf area and the relative leaf cover of weeds. Weed Sci., v. 47, n. 3, p. 297-304, 1999.
OBANDO, L. Potencial alelopático de Gliricidia sepium (Jacq.) Walp. sobre los cultivos de maiz y frijol y las malezas predominantes (abstract). In: WITHINGTON, D.; GLOVER, N.; BREWBAKER, J. L. (Ed.). Gliricidia sepium (Jacq.)

Walp.: management and improvement. Turrialba: Wiamanalo, Nitrogen Fixing Tree Association - NFTA, 1987. p. 59-60.

OLASANTAN, F. O; LUCAS, E. O.; EZUMAH, H. C. Effects of intercropping and fertilizer application on weed control and performance of cassava and maize. Field Crops Res., v. 39, n. 1, p. 63-69, 1994

RAJCAN, J.; SWANTON, C. J. Understanding maize-weed competition: resource competition, light quality and the whole plant. Field Crops Res., v. 71, n. 2, p. 139-150, 2001.

SISTEMAS PARAANÁLISES ESTATÍSTICAS - SAEG Versão 9.1. Viçosa, MG: Fundação Arthur Bernardes, UFV/ DBG, 2007.

SILVA, A. A.; VARGAS, L.; WERLANG, R. C. Manejo de plantas daninhas na cultura do milho. In: GALVÃO, J. C. C.; MIRANDA, G. V. Tecnologias de produção de milho. Viçosa, MG: Universidade Federal de Viçosa, 2004. p. $269-310$

SINGH, S. et al. Evaluation of mulching, intercropping with Sesbania and herbicide use for weed management in dry-seeded rice (Oryza sativa L.). Crop Prot., v. 26, n. 4, p. 518-524, 2007.

SKÓRA NETO, F. Controle de plantas daninhas através de coberturas verdes consorciadas com milho. Pesq. Agropec. Bras., v. 28, n. 10, p. 1165-1171, 1993.

THOMAS, P. E. L.; ALLISON, J. C. S. Competition between maize and Rottboellia exaltata. J. Agric. Sci., v. 84, n. 1, p. $305-312,1975$.

TIAN, G; KANG, B. T. Evaluation of Gliricidia sepium prunings for phytotoxicity on maize and cowpea seedlings. Agrofor. Syst., v. 26, n. 2, p. 249-254, 1994.

TOLLENAAR, M. et al. Effects of weed interference and soil nitrogen on four maize hybrids. Agron. J., v. 86, p. 596-601, 1994.

YAMOAH, C. F.; AGBOOLA, A. A.; MULONGOY, K. Decomposition, nitrogen release and weed control by prunings of selected alley cropping shrubs. Agrofor. Syst., v. 4 , n. 3 , p. $239-246,1986$ 